\title{
There Used to Be a Jewish Women, There Is No More Jewish Woman Now (Była Żydówka, nie ma Żydówki)
}

Author: Marian Pankowski

First Published: 2008

Translation: Italian (C'era e non c'era una volta un'ebrea, 2010).

About the Author: Marian Pankowski (1919-2011) was a novelist, playwright, and poet who was a prisoner at Auschwitz, Gross-Rosen, Mittelbau-Dora near Nordhausen, and Bergen-Belsen camps. After the war, he immigrated to Belgium, where he worked at the Universite Libre de Bruxelles and collaborated with the Paris-based literary-political magazine Kultura.

\section{Content and Interpretation}

Rather than writing about his own camp experiences, Pankowski's work consists in the writer's reflections on the stories of other survivors from a perspective of about sixty years after the war. In fourteen formally and materially diverse parts, Pankowski tells the story of the only survivor from the town of N., a Jewish girl by the name of Fajga Oberlender, who survived thanks to her mother's cleverness and the help of her neighbours. As Arkadiusz Morawiec points out, this is a story inspired by the wartime experiences of the writer's own wife, Regina Pankowska, who died in 1972. Regina Pankowska, née Fern, left Lviv in 1944 to take part in the Warsaw Uprising, marrying Marian Pankowski in 1950 (the name "Fajga" is ostensibly connected to Regina for sentimental reasons). The first part of the story concerns the protagonist's journey in 1950 to the fictional city of Azojville, U. S. - possibly a pseudonym for Asheville, North Carolina - where she is to present her survival story to members of the Association of Eastern European Jews. In this sense, Pankowski bases his story on a formula with universal appeal - or in any case, with an American audience in mind. She tells them how her mother saved her by dropping her from the railway embankment as she and other Jewish residents of their village were boarding a train to the death camps. Later, with the help of a Polish friend, she hid in a shed.

The essence of Pankowski's story is not the literary transposition of testimony, but a gesture that consists in problematising the manner in which stories of the Holocaust are told. It is a gesture that speaks not only to the narratives that circulate among American Jews, but to those about antisemitic pseudo-scholars, and to attitudes of Polish villagers towards the Holocaust: "For us Christians, the priest commands us to love thy neighbour as thyself. Anyway, Jews cannot become our fellow men. Jews are definitely alone” (Pankowski, 2008, pp. 29-30).

"On the Aging of Events and Jews Stripped of Their Humanity" is a pastiche of the attitude of the "typical" Pole who, despite the Holocaust, still considers Jews to be for- 
eigners. Another section with the title "Welcoming of Fajga Oberlender in the Jewish Community" reveals the untranslatability of the Holocaust experience and questions its supposed transnational nature (the locals ask, for example, "What is a 'szopa'?" [What is a shed?] p. 21). In another part, we find the "teachings" of a medieval entomologist, illustrated by reproductions of images depicting Jews as insects. One could argue that this tendency to compile a diversity of narrative material aims to demonstrate that Holocaust discourse today is not limited to the analysis of documents or oral history. Jakub Julian Ziółkowski's pastiches of caricatures of Jews, for example, constitutes an important part of the book as a whole. Only the combination of various narratives - the nexus, or chain of causality between stories - can give us an adequate understanding of the Holocaust in both its historical and futural aspects.

\section{Main Topics and Problems}

One of the main problems in There Used to Be a Jewish Women concerns Pankowski's approach to constructing the story, which represents a significant departure from the works of Irit Amiel or Michał Głowiński ( $\rightarrow$ Black Seasons), for example, whose works resemble accounts by first-hand witnesses, presenting personal stories in the first person voice. Pankowski's writing, by contrast, is a multi-voice, ironic pastiche of various genres, ranging from biblical narrative, through the poetry of Adam Mickiewicz, to eyewitness testimonies and philosophical stories. An important role is played by the author-narrator who comes to dominate the world he describes, guiding the course of events, and, as a character himself, introducing an element of artificiality into the story so as to compromise its sense of authenticity. This has much to do with the figure of the postmodernist narrator. In the novels of Raymond Federman, for example, the narrator is repulsed by literary pathos, and his digressions effectively introduce a space between himself and the events experienced by the protagonist. In this mode, the narration may have an informal quality, tending towards understatement, or resemble colloquial speech. In this way, we might consider Pankowski's novel as an example of the "postmodernisation" of the Holocaust. In addition to deconstructing genres, Pankowski deconstructs the language of the stories told in Poland about Jews and the Holocaust, especially folk proverbs and sayings, which turn out to transmit antisemitic content. Like Zofia Nałkowska in $\rightarrow$ Medallions, Pankowski portrays children as perpetrators of anti-Jewish hate speech. In one episode, children reveal where Oberlender is hiding, all the while singing "There used to be a Jewish woman, and there is no more Jewish woman now" (p. 61) and playing a game that resembles blind man's bluff.

According to Piotr Krupiński, the antisemitic behaviour of Poles in this novel takes part in the on-going process of dehumanisation that reduces Jews and Jewishness to the category of the inhuman. Borrowing from the ecological works of Konrad Lorenz and Karl Friedrichs, we note that the racial epithets used against the Jews in There Used to Be a Jewish Women tend to link them to those animals - cats, snakes, cockroaches, insects - most marked by cultural fear and contempt. In what is argu- 
ably the most striking of these epithets - the comparison of Jews to insects -, we see what Pankowski refers to as "species chauvinism" according to which insects are at the bottom of the pyramid of existence. The "insecto-Semitism" of the story, according to Monika Żółkoś, is, on the one hand, based on the persecution of both Jews and insects; on the other, this insistence on the "insect" existence of Jews becomes a special way to escape the policies of the Third Reich (Żółkoś, 2017, pp. 51-53). In There Used to Be a Jewish Women escape is metaphorically depicted as the protagonist's slipping away and suddenly disappearing, the insect's most characteristic mechanism of defence.

\section{Cited Works}

Pankowski, M. (2008). Była Żydówka, nie ma Żydówki. Warszawa: Wydawnictwo Krtyki Politycznej. Żółkoś, M. (2017). Insektosemityzm. Narracje o Zagładzie, (3), pp. 5165.

\section{Further References}

Bauer, I. (2014). Schreiben über den Holocaust. Zur literarischen Kommunikation in Marian Pankowskis Erzählung „Nie ma Żydówki“. Stuttgart: ibidem. Chałupnik, A. (2017). Niech się pan nie wyteatrza! Auschwitz w twórczości Mariana Pankowskiego. Warszawa: Wydawnictwo Uniwersytetu Warszawskiego. Cuber, M. (2013). Metonimie Zagłady. O polskiej prozie lat 1987-2012. Katowice: Wydawnictwo Uniwersytetu Śląskiego. Krupiński, P. (2011). About the Revolutions of a Planet Auschwitz. Marian Pankowski’s Lecture on Anti-Martyrological Literature. Russian Literature, 70(4), pp. 553571. Krupiński, P. (2016). „Dlaczego gęsi krzyczały?“ Zwierzęta i Zagłada w literaturze polskiej XX i XXI wieku. Warszawa: Instytut Badań Literackich PAN Wydawnictwo. Morawiec, A. (2016) Shoah in Marian Pankowski's Literary Art. Acta Universitatis Lodziesis. Folia Litteraria Polonica, 38(8), pp. 53-64. 